Kajian Jurnalisme

ISSN 2549-0559 (cetak) ISSN 2549-1946 (online)

Volume 02 Nomor 02 Tahun 2019

\title{
Jurnalisme Data Dalam Digitalisasi Jurnalisme Investigasi Tempo
}

\author{
Adithya Asprilla dan Nunik Maharani \\ Program Studi Jurnalistik, Fakultas Ilmu Komunikasi, , Universitas Padjadjaran, E-mail: \\ asprilladt@gmail.com
}

\begin{abstract}
This entitled Data Journalism on Digitalization of Investigative Journalism in Tempo research was aimed to determine why and how digitalization media used on data journalism for investigative journalism in Tempo. This research uses a qualitative method with explanatory case study of Robert K. Yin to elaborate the purposes. As well as using new media theory, mediamorfosis theory, and data journalism concept to analyze research and get the goals. The results showed that the reason why Tempo used data journalism on their investigative journalism is that they want to strengthen the differentiation and in line with their vision of digitalization media. Also, digitalization media and data journalism on Tempo's investigative journalism can maximize contents results. Applying digitalization media and data journalism also influenced the mindsets on the editorial staff. The conclusions of this research are Tempo has a vision on their process of digitalization media. The existence of data journalism turns out in line with their vision, and it is reinforced with the presence of news applications that offer creative space for investigative content based on processed data. The applications can be Tempo's support to attract the millennial generation readership to support the existence of the media itself.
\end{abstract}

Keywords: Case Studies, Data Journalism, Investigative Journalism, Media Digitalization, Tempo Keywords: Case Studies, Data Journalism, Investigative Journalism, Media Digitalization, Tempo

\begin{abstract}
Abstrak
Penelitian dengan judul Jurnalisme Data dalam Digitalisasi Jurnalisme Investigasi Tempo ini bertujuan untuk mengetahui mengapa dan bagaimana digitalisasi media digunakan dalam jurnalisme data pada kerja jurnalisme investigasi Tempo. Penelitian ini menggunakan metode kualitatif dengan pendekatan studi kasus eksplanatoris Robert K. Yin, serta menggunakan teori media baru, teori mediamorfosis, dan konsep jurnalisme data untuk menganalisa penelitian dan mendapatkan tujuan tersebut. Hasil penelitian ini menunjukkan Tempo menerapkan jurnalisme data dalam investigasinya guna menegaskan diferensiasi; sejalan dengan visi digitalisasi media yang mereka canangkan, serta agar dapat memaksimalkan hasil akhir konten. Penerapan digitalisasi media dan jurnalisme data tersebut turut berpengaruh pada penyesuaian pola berpikir di jajaran redaksi. Simpulan dari penelitian ini adalah Tempo memiliki visi dalam proses digitalisasi media yang mereka lakukan. Adanya jurnalisme data ternyata sejalan dengan visi digitalisasi Tempo dan ini dipertegas dengan kehadiran aplikasi yang menawarkan ruang kreatif untuk konten investigasi berbasis olahan data. Aplikasi tersebut dapat menjadi penopang Tempo dalam menarik jumlah pembaca generasi milenial demi menunjang keberlangsungan media tersebut.
\end{abstract}

Kata kunci: Digitalisasi Media, Jurnalisme Data, Jurnaslime Investigasi, Studi Kasus, Tempo 
213 | Kajian Jurnalisme

ISSN 2549-0559 (cetak) ISSN 2549-1946 (online)

Volume 02 Nomor 02 Tahun 2019

\section{Pendahuluan}

Berangkat dari jutaan dokumen finansial dari sebuah firma hukum asal Panama, investigasi berskala internasional pun dilakukan. Dokumen-dokumen tersebut bocor dan mengungkapkan bagaimana jejaring korupsi dan kejahatan pajak para kepala negara, agen rahasia, pesohor sampai buronan, disembunyikan di surga bebas pajak. Luke Harding dalam kata pengantar The Panama Papers: Breaking the Story of How Rich and Powerful Hide Their Money mengatakan hampir 400 jurnalis bekerja secara diam-diam pada kasus Panama Papers sepanjang 2016. Semuanya sepakat untuk melakukan publikasi investigasi pada 3 April (Obermayer \& Obermaier, 2016).

Di Indonesia, usutan tersebut dipublikasikan oleh Tempo pada 4 April 2016. Tempo merupakan satu-satunya media di Indonesia yang tergabung dalam kolaborasi lintas negara ini. Panama Papers masuk dalam file sebesar 2,6 terabyte (TB). Ada 4,8 surel; 3 juta database; 2,1 juta dokumen PDF; 1,1 juta foto, 320.000 dokumen teks; dan 2.000-an file lainnya (Wadrianto, 2016).

Tidak hanya pada kasus Panama Papers saja, Tempo turut menggunakan metode jurnalisme data dalam praktik jurnalisme investigasinya pada kasus Perdagangan TKI di Malaysia edisi 20 - 26 Maret 2017. Berdasarkan penelusuran sepanjang 2015-2016, lebih dari 2.200 warga Nusa Tenggara Timur (NTT) menjadi korban human trafficking oleh jaringan perekrut calon TKI di Kupang. Jaringan ini menyuplai tenaga kerja ilegal kepada minimal dua perusahaan induk berbeda, yaitu ManPower 88 milik Albert Tei dan NG Bersatu Sdn Bhd milik Oey Wenny Gotama (Rosarians, 2017).

Kasus investigasi berbasis jurnalisme data berikutnya adalah "Budak Indonesia di Kapal Taiwan” yang terbit pada edisi 9 - 15 Januari 2017 lalu. Investigasi tersebut menguak kasus anak buah kapal (ABK) lewat jalur ilegal asal Indonesia. Di mana praktik perdagangan manusia dan perbudakan tersebut mengakibatkan salah seorang ABK, Supriyanto, meninggal dunia karena disiksa selama berada di atas kapal. Di lain pihak, saat ini terdapat lebih dari 40.000 ABK Indonesia di kapal Taiwan yang beroperasi di laut lepas. Meski begitu, hanya ada 8.765 ABK Indonesia yang tercatat resmi di Taiwan.

Data sebesar tersebut dapat dikategorikan sebagai big data. Big data menjelaskan sekumpulan set data yang sangat besar - biasanya disimpan dalam storage/server karena mampu menyimpan lebih banyak data - yang dapat diolah untuk menemukan pola, tren, dan asosiasi yang berhubungan dengan perilaku dan interaksi manusia (Yudiantika, 2016).

Agar data tersebut dapat bernilai, maka perlu diolah menjadi informasi. Frasa jurnalisme data pun dihadirkan untuk tujuan yang sedikit berbeda dengan jurnalisme secara umum. Istilah jurnalisme data — atau biasa disebut data-driven journalism - mulai digunakan sejak 2009. Istilah ini menggambarkan proses jurnalistik berdasar pada analisis dan penyaringan set data untuk membuat berita (Yudiantika, 2016).

Seperti yang dilakukan Tempo saat dihadapkan dengan kesempatan untuk mengulik data-data dan mengolahnya menjadi karya jurnalisme investigasi. Sebab jurnalis data dan desainer informasi asal Inggris, David McCandless, memaparkan analisis data adalah "cara http://jurnal.unpad.ac.id/kajian-jurnalisme 
pandang baru" saat menjelaskan suatu masalah. Melalui analisis data, wartawan bisa menggeser fokus utama profesi dari "seseorang yang paling pertama melaporkan sebuah berita" menjadi "orang pertama yang melaporkan apa yang sesungguhnya terjadi".

Hal tersebut relevan bila disandingkan dengan produk investigasi. Laporan investigasi adalah sebuah metode jurnalistik dengan cara penelisikan atau penyelidikan. Gunanya untuk mengungkap informasi yang tersembunyi dan ditutuptutupi. Baik yang dilakukan individu, institusi pemerintah, dan swasta (Sumaatmadja, 2005).

Artinya bila Tempo menerapkan jurnalisme data, itu sama dengan membantu kinerja jurnalisme investigasi guna menguak apa yang sebenarnya terjadi dan berhak publik ketahui. Jurnalisme data memberikan banyak peluang dalam proses jurnalisme investigasi. Mulai dari pencarian berita, proses memvisualkan data untuk penyajian berita yang lebih kreatif, serta penggunaan data sebagai bukti sahih. Sebab selain melalui wawancara dan investigasi, penggunaan data yang valid dapat menjadi fakta kuat dalam sebuah berita.

Terlebih bila dilihat dari tren media saat ini, Tempo pun mau tidak mau harus mengikuti perubahan dari digitalisasi media. Media, termasuk Tempo dengan aliran investigasinya, harus melakukan adaptasi dalam bekerja. Cara menulis berita, mendekati narasumber, mencari bahan berita itu beradaptasi.

Terlebih bila dilihat dari tren media saat ini, Tempo pun mau tidak mau harus mengikuti perubahan dari digitalisasi media. Philipus pun menambahkan bahwa lingkungan berita saat ini sudah berubah dan berkembang. Media, termasuk Tempo dengan aliran investigasinya, harus melakukan adaptasi dalam bekerja. Cara menulis berita, mendekati narasumber, mencari bahan berita itu beradaptasi.

Tempo pun saat ini sedang dalam tahap untuk mengembangkan produk digitalnya. Baik Koran Tempo dan majalah Tempo keduanya akan tetap hadir sama persis bentuknya dengan versi cetak, tapi akan diperkaya dengan format digital. Menurut Direktur Pemberitaan Tempo, Arif Zulkifli, tujuannya diganti menjadi versi digital untuk mempermudah pembaca mengakses Tempo (Hidayat, 2017).

Ke depannya konsep jurnalisme tidak bisa hanya mengandalkan interview dan observasi saja, tapi data juga diperlukan bagi media. Jurnalisme data pun dinilai sangat penting dan menjadi salah satu strategi media bagi Tempo untuk memberikan diferensiasi di platform digital. Prospek digitalisasi media yang akan terus berkembang memungkinkan penelitian semacam ini dilanjutkan untuk beberapa tahun ke depan.

Adanya perkembangan yang dilakukan Tempo dalam menggunakan jurnalisme data untuk jurnalisme investigasi menjadi alasan peneliti memilih topik ini. Peneliti tertarik untuk menganalisis bagaimana media dengan produk andalan jurnalisme investigasinya tersebut dapat berkembang, terutama berkaitan dengan digitalisasi media dan peran jurnalisme data dalam membantu Tempo mendapatkan fakta untuk diolah nantinya.

Peneliti kaitkan teknologi informasi ini dengan kajian jurnalistik data dan investigasi di Indonesia. Perkembangan media massa dan teknologi komunikasi terus berkembang dan berjalan beriringan. Beriringan yang peneliti maksud adalah perkembangan teknologi http://jurnal.unpad.ac.id/kajian-jurnalisme 
215 | Kajian Jurnalisme

ISSN 2549-0559 (cetak) ISSN 2549-1946 (online)

Volume 02 Nomor 02 Tahun 2019

komunikasi yang terus diadaptasi oleh media massa. Dalam penelitian ini, peneliti fokus pada pengaruh teknologi informasi pada media massa.

\section{Metode}

Pada penelitian ini, peneliti menggunakan metode penelitian kualitatif. Penelitian kualitatif dimaksudkan untuk menghasilkan data deskriptif berupa kata-kata tertulis atau lisan dari orang-orang dan perilaku yang dapat diamati (Moleong, 2006). Termasuk untuk membentuk peneliti memahami lingkungan peneliti, subjek peneliti, dan menghubungkan teori-teori yang digunakan peneliti untuk mengupas penelitian ini.

Di sisi lainnya, fokus masalah dalam penelitian ini akan berkenaan dengan pendekatan studi kasus. Menurut Robert K. Yin (1996) dalam buku Studi Kasus: Desain dan Metode, studi kasus merupakan strategi yang cocok bila pokok penrtanyaan suatu penelitian berkenaan dengan bagaimana (how) dan mengapa (why). Kriteria pertanyaan ini sudah sesuai dengan pertanyaan yang tergambar pada identifikasi masalah penelitian.

Selain itu, strategi studi kasus menjadi cocok apabila peneliti hanya memiliki sedikit peluang untuk mengontrol peristiwa-peristiwa yang akan diteliti dan bilamana fokus penelitiannya terletak pada fenomena kontemporer (masa kini) di dalam konteks kehidupan nyata. Secara lebih spesifik, Robert K. Yin membagi pendekatan studi kasus ke dalam tiga tipe yaitu eksploratoris, eksplanatoris, dan deskriptif yang perbedaannya terletak pada jenis pertanyaan yang digunakan.

Jenis studi kasus yang digunakan peneliti adalah tipe eksplanatoris. Tujuan eksplanatoris adalah menggambarkan penjelasan yang berbeda dalam rangkaian peristiwa yang sama dan menunjukan bagaimana penjelasan semacam itu bisa diterapkan pada situasi yang lain (Yin, 1996). Alasan pemilihan eksplanatoris didasari oleh kesamaan tujuan dan didasari oleh pertanyaan utama dalam penelitian ini adalah tentang mengapa dan bagaimana jurnalisme data dapat berkontribusi pada digitalisasi praktik jurnalisme investigasi Tempo.

\section{Hasil dan Pembahasan}

Peneliti telah merangkum apa saja alasan yang membuat Tempo menerapkan jurnalisme data untuk jurnalisme investigasi, beberapa alasan di antaranya adalah:

1. Mewujudkan dan memaksimalkan visi fully digital newsroom

2. Menguatkan diferensiasi investigasi Tempo

3. Pemberdayaan media lewat mempelajari dan mencari inovasi baru

4. Melawan fenomena hoax news lewat perubahan pola produksi berita

5. Membantu mencari fenomena atau pola yang terjadi di masyarakat

6. Membuat investigasi lebih objektif

7. Memuat isu yang lebih relevan dengan publik dan tidak didorong kepentingan golongan tertentu

8. Prospek bisnis dan praktik jurnalisme data yang akan terus berkembang

Delapan poin tersebut merupakan alasan Tempo menerapkan jurnalisme data dalam jurnalisme investigasi. Kembali, hal tersebut dapat dikaitkan dengan pengertian mediamorfosis 
Kajian Jurnalisme

ISSN 2549-0559 (cetak) ISSN 2549-1946 (online)

Volume 02 Nomor 01 Tahun 2019

oleh Fidler. Aspek yang begitu relevan dengan jurnalisme data adalah inovasi sosial dan teknologi.

Ini pun mengantarkan peneliti untuk membahas konsep pertama dari mediamorfosis, yakni koevolusi. Koevolusi adalah proses adaptasi dari masa ke masa tanpa meninggalkan bentuk lamanya. Adanya perbedaan CAR dan jurnalisme data pun sempat dialami Tempo, khususnya dalam investigasi, dengan menggunakan data sebagai lampiran.

"Perbedaannya adalah sekarang media menyadari ini sebuah teknik yang bisa mengubah dan menjanjikan cara bercerita baru. Kalau dulu mungkin dianggapnya agak susah membuat apa yang dilakukan Metta dengan jurnalisme investigasi biasa. Tidak dipahami sebagai sebuah genre yang baru. Dua tahun terakhir media di Indonesia mulai menyadari bahwa ini adalah genre yang baru karena dia menjanjikan temuan-temuan yang lebih komprehensif. Menyajikan cerita yang di luar tafsir-tafsir mainstream karena media bisa langsung mengolah data mentah dari lembaga-lembaga survei atau penelitian." (Wawancara peneliti dengan Wahyu Dhyatmika pada 8 Agustus 2017).

Selain karena mulai terbangunnya kesadaran di Indonesia belakangan ini, menurut Wahyu Tempo perkembangan jurnalisme data di Tempo juga terjadi karena penetrasi internet dan perkembangan teknologi yang semakin kuat, berbeda dengan zaman 2000-an awal di mana internet dan media daring belum terlalu masif perkembangannya. Perkembangan berikutnya dari jurnalisme data di Tempo menurut Wahyu juga diperkuat dengan mulai maraknya ketersediaan open data. Di mana pemerintah semakin menyadari dan mendorong keterbukaan data.

Kaitannya tidak hanya dari benchmark visi tersebut, tapi pada produk akhir dari jurnalisme data yaitu proses mengkomunikasikan atau visualisasi olahan data. Wahyu mengatakan jurnalisme data adalah fitur yang tidak dapat dilepaskan dari digitalisasi media. Ada karya investigasi pada saat publikasi membutuhkan visualisasi data dan banyak dimungkinkan dari bantuan teknologi, kembali lagi pada poin adanya Tempo versi digital untuk membantu penekanan segmentasi generasi milenial dengan memperbanyak konten visual.

"Today, many journalist devote attention not only to finding data for investigations, but to publishing it alongside living stories, or news apps. News applications are one of the most important new storytelling forms of this young millenium, native to digital media, and, often, accessible across all browsers, devices, and operating systems on the open Web." (Howard, 2014).

Adanya news apps dengan konten investigasi berbasis data yang atraktif menjadi penopang dari digitalisasi media yang sedang dilakukan oleh Tempo. Itu adalah benang merah dari tatanan media baru, mediamorfosis, dan konsep jurnalisme data pada penelitian ini.

"Data journalism is just another tool by which we will navigate the digital space. New digital technologies bring new ways of producing and disseminating knowledge in society. Data journalism can be understood as the media's attempt to adapt and

http://jurnal.unpad.ac.id/kajian-jurnalisme 
217 | Kajian Jurnalisme

ISSN 2549-0559 (cetak) ISSN 2549-1946 (online)

Volume 02 Nomor 02 Tahun 2019

respond to the changes in our information environment, including more interactive, multidimensional storytelling enabling readers to explore the sources underlying the news and encouraging them to participate in the process of creating and evaluating stories." (Gray, Bounegru, \& Chambers, 2012).

Penerapan jurnalisme data pada media menurut Wahyu (dalam Utama, 2016) sebaiknya mulai dilakukan. Media dapat merombak dan memasukan unsur jurnalisme data karena pada akhirnya alur produksi berita harus disesuaikan dengan perkembangan teknologi. Ini sejalan dengan pernyataan Lorenz (2010) yang mengatakan jurnalisme data dapat membawa kesempatan besar dalam meniupkan semangat baru pada jurnalisme. Jika dilakukan dengan baik, menyediakan berita berbasis data dapat membangkitkan pendapatan dan membuka model bisnis yang tidak hanya mengandalkan langganan dan iklan. Sehingga bila dikaitkan dengan keinginan Tempo melakukan digitalisasi media, menerapkan jurnalisme data dapat menguatkan tujuan tersebut untuk dapat survive di era digital saat ini.

Dalam kaitannya produk multimedia dengan elemen susunan sosial dan organisasi ini adalah keadaan struktur redaksi di Tempo. Seperti yang peneliti bilang, saat ini di Tempo sudah memiliki tim PPD yang dapat membantu proses digitalisasi media. Namun, belum ada tim data tersendiri yang seharusnya menjadi payung dari penerapan jurnalisme data. Hal ini bahkan turut dikeluhkan oleh Mustafa yang berharap seharusnya Tempo memiliki desk khusus data tersendiri.

"Kami masih dalam proses belajar karena ini sesuatu yang baru diterapkan oleh kami. Evaluasinya kami masih perlu belajar banyak. Ini baru dan sumber daya manusianya juga harus di-upgrade. Koordinasi harus diperbaiki. Seperti yang ada di media luar negeri, seharusnya ada tim tersendiri. Kami masih comot sini, comot sana." (Wawancara peneliti dengan Mustafa Silalahi pada 2 Agustus 2017).

Ini pun berkaitan dengan konsep kompleksitas dari mediamorfosis. Sampai saat ini bila ada desk tertentu, termasuk investigasi, yang hendak menerapkan jurnalisme data, mereka mengaku masih kesulitan dalam melakukan proses pekerjaan. Sejauh ini penerapan jurnalisme data masih menjadi tanggung jawab atau 'tugas' tambahan dari setiap individu. Padahal, pengerjaan jurnalisme data memakan waktu dan tenaga. Peneliti beranggapan hal tersebut sulit untuk diterapkan ketika setiap individu tersebut memiliki tugas utama lainnya.

"Banyak perusahaan memilih untuk menggunakan 'wartawan multitasking'. Terdapat resiko pada kondisi seperti ini karena media akan mengubah tren menjadi 'alasan' untuk memotong biaya lewat cara 'do more with less' yang dapat berdampak pada berkurangnya kualitas produk akhir berita." (Siapera \& Veglis, 2012: 50).

Menurut Mustafa, persoalan kurangnya waktu begitu berpengaruh dengan hasil akhir dari investigasi. Bila ada penelusuran investigasi, termasuk saat menerapkan jurnalisme data, hanya berakhir in-depth, itu diakibatkan kurangnya waktu yang dialami oleh tim investigasi dalam menggarap suatu isu.

Setelah hasil penelitian dari hasil digitalisasi media dan jurnalisme data pada jurnalisme investigasi Tempo dijabarkan pada sub-bab sebelumnya, kali ini peneliti akan membahas hasil tersebut menggunakan konsep mediamorfosis dari Roger Fidler. 
Kajian Jurnalisme

ISSN 2549-0559 (cetak) ISSN 2549-1946 (online)

Volume 02 Nomor 01 Tahun 2019

Mediamorfosis dijelaskan sebagai proses transformasi media komunikasi yang biasanya ditimbulkan akibat hubungan timbal balik yang rumit antara berbagai kebutuhan yang dirasakan, tekanan persaingan dan politik, serta berbagai inovasi sosial dan teknologi (Fidler, 2003). Sejumlah aspek yang dikatakan oleh Fidler tersebut turut berdampak pada kemajuan media di era digital yang membuat Tempo melakukan digitalisasi media.

Tekanan persaingan yang dimaksudkan oleh Fidler pada penjelasannya mengenai mediamorfosis mengantarkan peneliti membahas konsep pertama yaitu kompleksitas. Dalam kompleksitas terdapat komponen penting yaitu chaos. Kekacauan yang dimaksud dapat timbul jika terjadi suatu perubahan, seperti halnya dalam transformasi media. Kekacauan tersebut sebenarnya dapat menjadi indikator penting dalam proses mediamorfosis.

Lalu kekacauan apa yang dialami oleh Tempo? Salah satu indikator utamanya adalah persaingan bisnis media yang bertransformasi digital. Tekanan tersebut memengaruhi Tempo dari hulu hingga hilir. Adanya kekacauan dalam ranah bisnis media tersebut sesuai dengan pengertian kompleksitas sendiri, di mana pada tepitepi kekacauan tersebut muncul gagasangagasan baru untuk bertahan hidup (Fidler, 2003: 43).

Menurut Wahyu, media yang tidak dapat bertahan di era digitalisasi media saat ini adalah mereka yang memilih tidak mengubah atau yakin dengan value yang dipegangnya sehingga merasa tidak perlu merasa untuk berubah. Pernyataan Wahyu tersebut menandakan saat ini Tempo sedang ada di salah satu konsep mediamorfosis, yakni koevolusi.

Proses adaptasi dalam koevolusi tersebut Tempo coba wujudkan dengan pengubahan format digital medianya. Sebagai media cetak yang berusaha adaptasi dengan platform digital, Wahyu menjelaskan terdapat beberapa downset yang harus Tempo ubah supaya bisa bertahan di era digital ini. Tempo memiliki sejarah, kebiasaan, dan tradisi yang tidak semuanya compatible dengan teknologi digital sehingga harus melakukan adaptasi dan prosesnya akan membutuhkan waktu.

Dalam penerapannya, Tempo mencoba melakukan adaptasi dengan visi fully digital newsroom 2020 yang sempat peneliti singgung sebelumnya. Salah satu tujuan visi tersebut adalah untuk mengubah seluruh outlet Tempo menjadi digital. Untuk mengupayakan visi tersebut, Tempo memiliki lima benchmark yang diharapkan dapat membantu mewujudkannya. Lima benchmark tersebut terdiri dari interactive and collaborative, open and transparant, measurable, multimedia, serta platform driven.

Bukti keseriusan Tempo dalam mewujudkan visi tersebut bahkan sudah tertuang dalam Laporan Tahunan PT. Tempo Inti Media Tbk. pada 2016 kemarin. Perubahan pola konsumen di era digital ini membuat Tempo melakukan transformasi produk akhir yang tidak hanya disebarkan melalui media cetak saja, tapi juga versi digitalnya. "Media cetak yang berhasil memindahkan pembacanya ke produk digital pasti menekankan pada keunggulan dan kekayaan konten digital mereka. Konten digital itu harus layak untuk dibeli, worth the money. Kalau tidak, buat apa orang mengeluarkan uang untuk berlangganan? Kalau sekadar berita dengan teks dan foto, banyak media daring menawarkan konten serupa dengan gratis." (Utama, 2016).

http://jurnal.unpad.ac.id/kajian-jurnalisme 
219 | Kajian Jurnalisme

ISSN 2549-0559 (cetak) ISSN 2549-1946 (online)

Volume 02 Nomor 02 Tahun 2019

Inilah yang coba dilakukan oleh Tempo dalam menyajikan konten kreatif di media digitalnya. Yosep mengatakan di dalam media digital tersebut di dalamnya ada video, audio, visualisasi lainnya sekalipun bentuknya majalah atau koran digital. Selain lewat aplikasi, Tempo juga akan mempublikasikannya dalam daring dengan cara berlangganan. Jadi tidak hanya ada di Tempo.co saja, nanti pembaca dapat mengakses majalah.tempo.co dan koran.tempo.co yang saat ini sedang ada di tahap redesign.

Kembali peneliti cantumkan, masuknya proses yang dilakukan Tempo pada kategorisasi media baru terkait dengan salah satu faktor media tersebut melakukan digitalisasi, yakni penekanan segmentasi. Tempo ingin menyasar pembaca yang akrab dengan gawai, di mana segmentasi yang dimaksud adalah para pembaca baru dari generasi milenial yang sudah terbiasa dengan teknologi internet.

Tempo pun mengupayakan adaptasi dalam menyasar segmentasi tersebut. Sejalan dengan mengusung media digitalnya, majalah Tempo menjalankan program go younger, go investigative, dan go accurate untuk meraih lebih banyak pembaca, terutama pembaca muda (PT Tempo Inti Media Tbk., 2016). Menurut Mustafa, pernyataan tersebut dilakukan dengan cara memperbanyak konten di visual. Di mana media digital memberikan kesempatan untuk memberikan nilai lebih pada produk digital dan memanfaatkan materi yang tersedia. Selain itu, terdapat beberapa keunggulan lainnya yang ditawarkan dari produk digital.

Meski Tempo saat ini memiliki versi media digital, bukan tandanya Tempo akan meninggalkan versi media cetaknya. Ini mengingatkan soal penjelasan koevolusi dari Roger Fidler tentang proses adaptasi tidak meninggalkan bentuk media lamanya. Dalam proses digitalisasi media ini pun Tempo tetap mempertahankan nilai-nilai yang selama ini mereka pegang. Nilai-nilai tersebut adalah terpercaya, merdeka, dan profesional.

Nilai-nilai tersebut tetap dipertahankan meski media tersebut memiliki visi untuk melakukan digitalisasi media. Seperti yang sudah dipaparkan sebelumnya, Tempo memiliki tujuan untuk mengubah seluruh cara kerja media tersebut agar menjadi digital. Ini pun berdampak dengan mindset digital yang Tempo usaha tanamkan pada seluruh jajaran redaksinya. Apa yang dilakukan Tempo tersebut berkaitan dengan konsep mediamorfosis lainnya, yakni konvergensi.

Konvergensi jurnalistik mensyaratkan perubahan cara berpikir media tentang berita dan peliputannya. Dalam model konvergensi dari Grant dan Wilkinson (2009), tipe ini dapat diklasifikasikan dengan model konvergensi newsroom. Dalam konvergensi ini jurnalis yang berbeda platform menyatukan dirinya dalam satu ruang produksi berita dan mengerjakan tugas sesuai dengan platform medianya.

Pada awalnya, Tempo menerapkan konvergensi newsroom. Bahkan media tersebut memberi namanya dengan Tempo Newsroom (TNR). Sistem newsroom itu digunakan untuk menyatukan kompartemen-kompartemen pada platform Koran Tempo, MBM Tempo, dan Tempo.co. Pada saat itu, setiap kompartemen yang sama dari setiap platform digabungkan. Misalnya pada kompartemen Nasional atau EkonomiBisnis yang menjadi satu kompartemen besar pada newsroom tersebut.

http://jurnal.unpad.ac.id/kajian-jurnalisme 
Namun, saat ini model konvergensi newsroom tersebut sudah tidak diterapkan lagi oleh Tempo. Ini pun berkaitan dengan aspek kekacauan dari kompleksitas yang sempat peneliti sebut pada pembahasan method sebelumnya. Menurut Wahyu, penerapan konvergensi saat itu dinilai tidak efektif karena semua wartawan Tempo harus mengerjakan semua hal. Penerapan cara kerja tersebut justru merugikan kualitas berita yang diproduksi oleh Tempo serta tidak memberikan diferensiasi dan kekuatan produk akhir berita dari setiap platform.

Selain itu, Wahyu menambahkan wartawan cenderung menyamakan dan kehilangan sense pada kekuatan masingmasing platform ketika dituntut berpikir untuk banyak outlet. Pada akhirnya berdampak seperti ketika menulis berita daring secara cepat dan ringkas, malah menjadi bertele-tele dan panjang layaknya media cetak. Ketika menulis untuk majalah, berita menjadi dangkal dan tidak ada isinya. Menurut Wahyu pun para pembaca turut merasakan perubahan kualitas berita Tempo. Para pembaca merasa Tempo tidak lagi seperti dulu. Membaca majalah seperti membaca kliping koran, membaca Koran Tempo seperti membaca kompilasi-kompilasi berita daring, dan membaca media daring seperti membaca potonganpotongan majalah dan koran.

Maka dari itu, saat ini justru Tempo melakukan dekonvergensi newsroom sejak awal 2017. Tempo tidak lagi mengusung newsroom per kompartemen dan setiap platform memiliki redaksi masing-masing. Sehingga setiap wartawan hanya memiliki kewajiban untuk memproduksi berita sesuai platform-nya saja. Dampaknya, jelas Wahyu, tentu memberikan kondisi yang lebih baik bagi Tempo.

Dalam model konvergensi dari Grant dan Wilkinson (2009), tipe ini dapat diklasifikasikan sebagai model konvergensi gathering. Seorang jurnalis dituntut untuk mampu mencapai tingkatan multitasking agar dapat melakukan pekerjaan yang dilakukan oleh media dengan platform lain dalam satu grup. Pada kasus Tempo, konvergensi news gathering awalnya dilakukan agar wartawan dapat menulis berita dengan standar penulisan media cetak, sekaligus menjadi penulis berita online yang memberikan berita cepat, keterbaruan, terus-menerus, dan ringkas. Namun karena saat ini sudah dilakukan dekonvergensi newsroom, wartawan Tempo lebih dituntut untuk menghasilkan berita dengan konten yang beragam.

Berita akhirnya disuguhkan dalam bentuk multimedia, yang merupakan kombinasi antara teks, gambar, audio, video, dan pilihan lainnya yang terus berkembang. Hal tersebut dituangkan dalam misi media tersebut untuk menghasilkan produk multimedia yang independen dan bebas dari segala tekanan dengan menampung dan menyalurkan secara adil suara yang berbeda-beda. Tempo pun memiliki misi untuk menghasilkan produk multimedia bermutu tinggi dan berpegang pada kode etik. Sehingga nantinya diharapkan dapat menjadi pemimpin pasar dalam bisnis multimedia dan pendukungnya. Sehingga wartawan Tempo diminta agar dapat menghasilkan produk berita yang beragam seperti audio serta video, jadi tidak sebatas teks saja.

Meski Tempo sudah melakukan dekonvergensi newsroom, tetap saja pada praktiknya Tempo saat ini masih berdasarkan konvergensi untuk menghasilkan karya multimedia mengingat adanya proses digitalisasi media yang mereka canangkan. Caranya adalah dengan 
221 | Kajian Jurnalisme

ISSN 2549-0559 (cetak) ISSN 2549-1946 (online)

Volume 02 Nomor 02 Tahun 2019

menanamkan mindset digital pada seluruh jajaran redaksi. Mindset digital tersebut ada tiga faktor agar dapat memformat ulang ruang redaksi. Pertama, bagaimana wartawan memandang tugas dan cara kerja ruang redaksi. Kedua, bagaimana media memandang audiens. Ketiga, bagaimana mendistribusikan kerja jurnalistik kepada audiens.

"We are in the middle of transition karena itu banyak sekali hal-hal yang belum kami lakukan. Secara kultur misalnya kami masih belum sepenuhnya digital. Tenggat penyelesaian naskah kami masih berorientasi pada produksi cetak.

Belum semua redaksi memahami pentingnya digitalisasi media. Maksudnya adalah di kami mesin cetak itu mulai bekerja Kamis atau Jum'at. Kami mulai persiapkan untuk penerbitan pada Senin. Jadi deadline itu Jum'at dan kami baru cetak pada Sabtu. Jadi seluruh schedule produksi itu ditentukan oleh kapan itu mau dicetak. Ke depan tidak harus seperti itu. Kalau distribusinya mainly digital, schedule cetak jadi less-important. Tergantung pada ceritanya. Misalnya ceritanya lebih cocok untuk ibu-ibu soal harga susu terkontaminasi. Ibuibu suka online pada hari apa? Biasanya Selasa. Baru kami terbitkan pada Selasa.” (Wawancara peneliti dengan Wahyu Dhyatmika pada 4 Agustus 2017).

Selain secara kultur, tambah Wahyu, keseluruhan konsep pada struktur di Tempo sebagai sebuah redaksi digital itu belum sepenuhnya terimplementasi. Tempo menilai struktur pun harus disiapkan compatible dengan platform digital. Dalam menyempurnakan tatanan, pandangan Wahyu sebagai ahli mengatakan ini penanaman mindset digital bukan soal sederhana. Sebab transisi dari media cetak ke media digital membutuhkan paradigm shift yang amat mendasar di ruang redaksi. Redaksi tidak bisa lagi bekerja berdasarkan pembagian kerja yang baku: wartawan, fotografer, videografer, informasi dan dokumentasi, riset, dan lain-lain, melainkan menjadi sebuah tim digital yang bahu-membahu dengan kompetensi masingmasing. Semua harus memahami setiap aspek, meski spesialisasi tetap dibutuhkan. Sehingga hubungannya bila pada akhirnya penanaman mindset tersebut dapat terimplementasikan dengan baik, kekayaan konten pun akan muncul beriringan di media digital karena tidak hanya berpikir untuk menyiapkan konten pada media cetak saja.

Proses digitalisasi media tersebut tentu beriringan dengan penerapan jurnalisme data di jurnalisme investigasi Tempo. Proses kerja dari penerapan jurnalisme data tidak banyak berbeda dari cara kerja jurnalistik pada umumnya. Proses seperti merencanakan liputan, melakukan verifikasi, menulis berita, hingga mempublikasikannya masih dapat ditemukan pada metode jurnalisme data. Meski begitu, terdapat beberapa tahap spesifik yang membuat peran dan fungsi jurnalisme data berbeda dari praktik jurnalisme kebanyakan.

Penerapan jurnalisme data di Tempo sudah sesuai dengan lima tahapan piramida terbalik dari Paul Bradshaw (2011) soal proses kerja jurnalisme data.

Lewat lima tahapan ini tim investigasi Tempo dapat menunjukan sebuah data set dapat diolah menjadi produk jurnalistik. Tahapan tersebut dimulai dari proses mengumpulkan, membersihkan, kontekstualisasi, menggabungkan, dan akhirnya data tersebut dapat dikomunikasikan kepada khalayak.

http://jurnal.unpad.ac.id/kajian-jurnalisme 
Kajian Jurnalisme

ISSN 2549-0559 (cetak) ISSN 2549-1946 (online)

Volume 02 Nomor 01 Tahun 2019

\section{Simpulan}

Berdasarkan hasil penelitian mengenai proses digitalisasi media yang digunakan dalam jurnalisme data pada kerja jurnalisme investigasi Tempo, dapat disimpulkan penerapan jurnalisme data oleh Tempo dalam proses investigasinya dilakukan karena ingin mempertegas kekhasannya sebagai media investigatif. Tidak hanya memperkuat dari sisi kualitas akurasi berita saja, penerapan jurnalisme data tersebut sejalan dengan visi digitalisasi Tempo. Hadirnya news apps Tempo menawarkan ruang kreatif untuk mengomunikasikan olahan data menjadi konten kreatif. Proses publikasi melalui news apps pun menjadi tren penerapan jurnalisme data saat ini dan cukup populer di generasi milenial. Dari segi redaksi pun Tempo sudah menyadari pentingnya saat ini media tidak hanya dapat ditopang oleh wartawan atau reporter saja. Melainkan aspek keahlian lainnya yang dapat menunjang penerapan jurnalisme data dan digitalisasi media tersebut pun Tempo perlukan.

Selain itu, digitalisasi media dan jurnalisme data membantu Tempo dalam menguatkan diferensiasi media tersebut dalam menghasilkan karya investigasi. Selain itu, Tempo turut menilai kemampuan menerapkan jurnalisme data sebagai kelebihan media digital belum banyak digali di Indonesia. Ini sesuai dengan penjelasan Roger Fidler dari segi mediamorfosis soal perubahan dapat terjadi karena ada persaingan dan inovasi dalam ranah media. Sehingga Tempo melihat digitalisasi media dan jurnalisme data menempati posisi teknologi yang akan terus berkembang sebagai proses kerja dan tulang punggung jurnalistik ke depannya.

Tempo membekalkan diri dengan visi fully digital newsroom dalam proses penerapan digitalisasi dan jurnalisme data di medianya. Salah satu tujuan visi tersebut berbicara soal bagaimana jajaran redaksi di Tempo menyesuaikan pola berpikir dalam proses perkembangan media. Langkah penyesuaian struktur redaksi dan cara kerja diambil Tempo guna membantu pencapaian visi tersebut. Ini sesuai dengan penjelasan Roger Fidler dari segi mediamorfosis soal transformasi atas masing-masing entitas yang bertemu dan penciptaan entitas baru.

Terakhir, penggunaan jurnalisme data oleh Tempo dalam proses jurnalisme investigasinya adalah dengan menjadikan data sebagai ujung tombak liputannya sejak perencanaan hingga evaluasi. Tim investigasi pun sudah menggunakan data sebagai bahan utama dan proses awal mula proses pengerjaan berita dan tidak menerapkan jurnalisme data hanya untuk lampiran saja. Dalam proses kerjanya pun tim investigasi sudah mengaplikasikan setiap tahapan piramida terbalik dari Paul Bradshaw (2011). Hanya saja saat ini kendala tim investigasi masih ada pada di bagian awal, yakni ketersediaan data dari pihak luar yang masih sporadis dan data valid sukar didapatkan. Dalam prospeknya pun Tempo memiliki rencana untuk mengajak publik berpartisipasi dalam proses jurnalisme data. Hal ini selain sejalan dengan visi fully digital newsroom Tempo, juga berhubungan dengan nilai interaktivitas dari tatanan media baru.

http://jurnal.unpad.ac.id/kajian-jurnalisme 
223 | Kajian Jurnalisme

ISSN 2549-0559 (cetak) ISSN 2549-1946 (online)

Volume 02 Nomor 02 Tahun 2019

\section{DAFTAR PUSTAKA}

\section{Buku:}

Fidler, R. (2003). Mediamorfosis: Memahami Media Baru. $\quad$ Yogyakarta: Bentang Budaya.

Grant, A. E. \& Wilkinson, J. S. (2009). Understanding Media Convergence: The State of the Field. New York: Oxford University Press.

Gray, J., Bounegru, L., \& Chambers, L. (2012). Data Journalism Handbook. California: O'Reilly Media.

Moleong, L. J. (2006). Metodologi Penelitian Kualitatif. Bandung: PT Remaja Rosdakarya.

Obermayer, B., \& Obermaier, F. (2016). The Panama Papers: Breaking the Story of How the Rich and Powerful Hide Their Money. London: Oneworld Publications.

Siapera, E. \& Veglis, A. (2012). The Handbook of Global Online Journalism. $\quad$ Oxford: Wiley-Blackwell.

Sumaatmadja, D. (2005). Reportase Investigasi: Menelisik Lorong Gelap. Jakarta: LaTofi Enterprise.

Yin, R. K. (1996). Studi Kasus: Desain dan Metode. Jakarta: Raja Grafindo Persada.

\section{Jurnal dan Artikel Ilmiah:}

Howard, A. B. (2014). The art and science of data-driven journalism: When journalists combine new technology with narrative skills, they can deliver context, clarity, and a better understanding of the world around us. New York: Columbia Journalism School.

Lorenz, M. (2010). Data-driven journalism: what is there to learn? Amsterdam: European Journalism Centre (EJC).

\section{Penelusuran Daring:}

Bradshaw, P. (2011, Juli 7). The Inverted Pyramid of Data Journalism. Dipetik Juli 4, 2017, dari Online

Journalism Blog: https://onlinejournalismblog.com/2 011/07/07/the-inverted-pyramid ofdata-journalism/

Hidayat, A. (2017, Juni 13). Koran Tempo Tetap Terbit, Versi Cetak Diperkaya Format Digital. Dipetik Juni 14, 2017, dari Tempo.co: www.tempo.co/read/news/2017/06/ 13/173884131/koran-tempo-tetapterbit-versi-cetdiperkayaformatdigital?utm_source= Digital+Marketing\&utm_medium $=$ Facebook\&ut m_campaign $=$ Nasional_O

Rosarians, F. (2017, Maret 23). Kasus TKI Ilegal, Pemerintah Telusuri Siapa Pengirimnya. Dipetik September 12, 2017, dari

Tempo.co:www.nasional.tempo.co/read/858768/kasus-tki-ilegal-pemerintahtelusuri siapa pengirimnya 
Kajian Jurnalisme

ISSN 2549-0559 (cetak) ISSN 2549-1946 (online)

Volume 02 Nomor 01 Tahun 2019

Utama, A. (2016, April 26). Dokumen Panama dan Masa Depan Jurnalisme Investigasi. Dipetik November 26, 2016, dari Remotivi: www.remotivi.or.id/amatan/282/Do kumen-Panama-dan-Masa-DepanJurnalisme-Investigasi

Wadrianto, G. K. (2016, April 4). Ada 2.961 Nama dari Indonesia di Bocoran

"Panama Papers". Dipetik April 26, 2017, dari Kompas.com: internasional.kompas.com/read/2016/04/04/19113441/Ada.2.961.Nam a.dari.Indonesia.di.Bocoran.Panama.Papers

Yudiantika, A. R. (2016, Juni 27). Jurnalisme Data dan 'Big Data'. Dipetik Juni 14, 2017, dari Pindai: pindai.org/2016/06/27/jurnalismedata-dan-big-data/

PT Tempo Inti Media Tbk. (2016). Laporan Tahunan. Jakarta: Tempo Media Group.

http://jurnal.unpad.ac.id/kajian-jurnalisme 